Sri Lanka J. Aquat. Sci. 14 (2009): 75-85

\title{
Lipid composition and fatty acid profiles of wild caught and fattened mud crab, Scylla serrata, in Sri Lanka
}

\author{
M.U.M. ANAS $^{1}, \quad$ E.M.R.K.B. EDIRISINGHE ${ }^{2^{*}}$ and J.M.P.K. \\ JAYASINGHE $^{1}$
}

${ }^{1}$ Department of Aquaculture and Fisheries, Faculty of Livestock, Fisheries and Nutrition, Wayamba University of Sri Lanka, Makandura, Gonawila (NWP), Sri Lanka

${ }^{2}$ Post Harvest Technology Division, National Aquatic Resources Research \& Development Agency, Crow Island, Colombo 15, Sri Lanka

*Corresponding author (E-mail: ranjith_e@hotmail.com)

\begin{abstract}
There is a huge demand for mud crab (Scylla serrata) in overseas markets. The mud crabs available to the market are mainly wild caught crabs and cage fattened crabs. Crab fattening is used to fatten the thin crab or post molt crab to fill up their meat in a shorter period. In the present study, lipid levels and fatty acid profiles of wild caught and fattened mud crabs at the harvested stage as well as at the stocking and harvesting stages of the fattening process were analyzed using gas chromatography. The total lipid content of wild caught (fattened) S. serrata $(0.65 \pm 0.1 \%)$ was significantly higher than that of cage fattened individuals $(0.56 \pm 1 \%)$. Polyunsaturated fatty acids were the predominant group of fatty acids found in S. serrata (39\%$43 \%)$ and Oleic acid (C 18:1 n-9) was the most abundant fatty acid (16\%21\%). Oleic acid (C 18:1 n-9), Gondoic acid (C 20:1), Eicosapentaenoic acid (C20: 5 n-3), Docosatetraenoic acid (C22: 4 n-6) and Docosahexanoic acid (C22: $6 \mathrm{n}-3)$ contents varied significantly between crabs at stocking and harvested stages of fattening process. The contents of Oleic acid (C 18:1 n-9), Gondoic acid (C 20:1) and Docosatetraenoic acid (C 22:4 n-6) were significantly different in wild caught crabs in comparison to fattened crabs. The differences in fatty acid composition among wild caught crabs (fattened stage) and cage fattened crabs (fattened stage) might be a reason for flavour difference between the two types.
\end{abstract}

\section{Introduction}

The mud crab Scylla serrata (Froskal) is one of the highly consumed crab species which is widely distributed in Indo-west pacific region. It belongs to the group of swimming crab Portunid, characterized by a flattened hind pair of legs. Mud crab is predominantly estuarine, but depends on 
marine environment for spawning and early larval life. S. serrata is one of the major species of crabs which has a very good market around the world. The meaty crabs weighing more than $300 \mathrm{~g}$ are considered as export quality (Jayamanne 1991) and they are currently exported to several countries including Singapore, Malaysia, Hong Kong, Japan and Spain (Anon. 2002).

Mud crabs available to the export market are wild caught crabs and cage fattened crabs. The wild caught crabs are meaty and are identified by pressing the branchial region with fingers to determine the hardness. The meaty crabs with hard exoskeleton are directly exported as wild caught crabs. They are highly priced in the market compared to fattened crabs due to their rich flavour. Watery crabs with soft exoskeleton are not qualified as export quality. After the ecdysis, crab is soft and watery until its new shell is fairly hardened by calcium carbonate deposits (Bliss 1990). Crab fattening method is used for fattening the thin crab or post molt crab (intermolt 1 stage) to fill up their meat or getting fat (fattened stage) in a short period. Crabs are stocked in mesh and/or bamboo cages or in ponds and fattened for 15 to 23 days by feeding with trash fish, fish offal, molluscs, etc (Anon. 2002). Crab fattening is currently practiced at brackish water bodies in Sri Lanka such as Negombo, Chilaw, Kalpitiya, Jaffna, and Trincomalee.

Dietary lipids are a major concern at present as they have both beneficial and harmful health implications. In crustaceans the edible parts are low in fat $(0.5$ to $1.5 \%)$, but they are rich in polyunsaturated fatty acids (PUFAs) of family n-3 including C20 and C22 with up to six double bonds (Ackman 2000). According to clinical and animal studies conducted during last 20 years, these dietary n-3 PUFAs are accepted as beneficial in reducing the certain risks of cardiovascular diseases. However recent studies suggested that not only the level of PUFAs but also the types of PUFAs need to be defined for recommendation of dietary PUFAs in dietary guidelines in future (Hwang 2000).

Although fattened and wild caught mud crabs are frequently consumed by people still there is a lack of information on their muscle lipid composition and fatty acid profile. As it is said to be a flavour difference between fattened and wild caught mud crabs, there might be a difference in muscle fatty acid profiles of crabs from those two sources. Also it is unknown whether there is a difference in muscle fatty acid profiles between beginning and end of the fattening. The aim of the present study was to compare the muscle fatty acid profiles of cage fattened (fattened stage or harvestable stage), wild caught (fattened stage or harvestable stage) and wild caught (intermolt I stage or stocking stage of cage fattening) mud crabs.

\section{Materials and Methods}

\section{Sample collection and preparation}

Samples of the $S$. serrata of the carapace length group 10 to $16 \mathrm{~cm}$ were collected from Negombo and Kalpitiya lagoons of the North Western 
coast of Sri Lanka from February 2006 to March 2006. Mud crabs from cage fattening facilities (fattened stage) and wild catches (both at fatten stage and intermolt I stage) were collected from each water source.

The individual samples were packed in polythene bags, immediately chilled in crushed ice from outside of the bags and transported to the laboratory of Post Harvest Technology Division, NARA. In the laboratory, carapace length and weight of each individual were measured, sex was determined, and exoskeleton was removed, repacked in labeled polythene bags and frozen at $-20{ }^{\circ} \mathrm{C}$ until further analysis.

\section{Lipid and fatty acid analysis}

The total lipid contents and fatty acid profiles of the body muscles were determined for 11 Wild caught (IM I stage) crabs, 13 Wild caught (fattened stage) crabs \& 13 cage fattened (fattened stage) crabs. Two replicates were taken from the each sample. Lipids were extracted and purified from the muscle sample and lipid content was determined using Bligh and Dyer method (Hanson and Olly 1965). Fatty acid methyl esters (FAME) of these lipids were prepared by base hydrolysis followed by transesterification (Berner and Berner 1994) and separated by capillary column chromatography using a Shimadzu GC $-14 \mathrm{~A}$ gas chromatograph with a supelco wax 10 fused silica capillary column (length $30 \mathrm{~m}, 0.32 \mathrm{~mm}$ ID, 0.25 $\mu \mathrm{m}$ film thickness). Helium was used as the carrier gas at a rate of $50 \mathrm{ml} / \mathrm{min}$. The split ratio was maintained at 1:50. The injection and the detector ports were operated at $240{ }^{\circ} \mathrm{C}$ and $250{ }^{\circ} \mathrm{C}$ respectively. The temperature program used in the oven was $60{ }^{\circ} \mathrm{C}$ to $240{ }^{\circ} \mathrm{C}$ at ${ }^{\circ} \mathrm{C} / \mathrm{min}$ and $6 \mathrm{~min}$ at $240{ }^{\circ} \mathrm{C}$. The separated compounds were detected using a hydrogen flame ionization detector. The obtained peaks were identified and quantitatively determined by comparing retention times of methyl esters in a standard mixture from Larodane fine Chemicals AB, Sweden.

\section{Data analysis}

The percentage lipid contents (pooled data from both Negombo and Kalpitiya lagoons) between three categories were compared statistically using ANOVA followed by Least Significant Difference Test (when significant differences were evident from ANOVA) to identify the categories among which significant differences exist. Then the percentages of each individual fatty acid were statistically compared using ANOVA. Whenever significant differences were evident, Least Significant Difference Test was performed to detect the pairs of categories with significant differences. Canonical discriminant analysis was carried out to test the separation of three categories based on the fatty acid profiles (The fatty acid profiles of 11 individuals from each category were considered in the analysis). In addition, discriminant analysis was conducted to test the separation of the fatty acid profiles (Pooled data of three categories) of crabs from two locations (Negombo and Kalpitiya 
lagoons) based on the fatty acid profile. Pooled t-test was carried out to test if there is any significant difference of the percentage of each individual fatty acid (pooled data from three categories) between two locations. Statistical software SPSS 13.0 was used for all the above statistical analyses.

\section{Results}

\section{Total lipid content and Fatty acid composition}

The total lipid content in the wild caught and cage fattened mud crabs is presented in Table 1 together with their body sizes. The total lipid contents were not significantly different between intermolt (IM I) and cage fattened (fattened stage) $(\mathrm{p}>0.05)$. However, wild caught individuals showed a significantly higher total lipid content than that of cage fattened crabs at fattened stage $(\mathrm{p}<0.05)$.

Table 1. Whole body weight, carapace length and total lipid contents of wild caught and fattened (stocking and harvested stages) Scylla serrata.

\begin{tabular}{lcccc}
\hline & $\begin{array}{c}\text { Number } \\
\text { of } \\
\text { samples }\end{array}$ & $\begin{array}{c}\text { Weight } \\
\mathbf{( g )}\end{array}$ & $\begin{array}{c}\text { Carapace } \\
\text { length } \mathbf{( c m )}\end{array}$ & $\begin{array}{c}\text { Lipid } \\
\text { content } \\
\mathbf{( \% )}\end{array}$ \\
\hline $\begin{array}{l}\text { Wild caught } \\
\text { (IM I stage) }\end{array}$ & 11 & $405.49 \pm 83.7$ & $13.72 \pm 0.7$ & $0.53^{\mathrm{a}} \pm 0.1$ \\
$\begin{array}{l}\text { Wild caught } \\
\text { (fatten stage) }\end{array}$ & 13 & $500.51 \pm 66.6$ & $14.8 \pm 1.7$ & $0.65^{\mathrm{b}} \pm 0.1$ \\
$\begin{array}{l}\text { Cage fatten } \\
\text { (fatten stage) }\end{array}$ & 13 & $279.81 \pm 93.5$ & $12.04 \pm 1.4$ & $0.56^{\mathrm{a}} \pm 0.1$ \\
\hline
\end{tabular}

Data are presented as mean \pm SD. Mean values in the same column followed by different letters are significantly different from each other $(\mathrm{p}<0.05)$.

The fatty acid composition of mud crabs belonging to wild caught (IM I stage), wild caught (fattened stage) and cage fattened (fattened stage) categories is presented in Table 2 where as summarized data for major groups of fatty acids are given in Table 3 . The most predominant fatty acids in mud crabs were pPalmitic acid (C 16:0), Oleic acid (C 18:1 n-9), Eicosapentaenoic acid (C 20:5 n-3), Eicosatetraenoic acid (C 20:4 n-3) and Docasahexaenoic acid(C 22:6 n-3). Saturated Fatty Acids (SFAs) contributed to a minor part of the fatty acid profile and ranged from $23 \%$ to $26 \%$ of total fatty acids (Table 3 ). This SFA group consisted of Myristic acid (C 14:0) Pentadecanoic acid (C 15:0) and Stearic acid (C 18:0) with Palmitic acid (C 16:0) contributing to the second largest proportion (15-17\%) of SFAs (Table 2). The Monounsaturated Fatty Acids (MUFAs) ranged between $25 \%$ and $29 \%$ of total fatty acids (Table 3). This group consisted of palmitoleic acid (C 16: 1), Vaccenic acid (C18: 1 n-7), Gondoic acid (C 20:1) and (C 24:1) with Oleic acid (C 18:1 n- 
9) contributing to largest proportion (16-21\%) of total fatty acids (Table 2). Polyunsaturated Fatty Acids (PUFAs) were the predominant group of fatty acids in S. serrata, and ranges from $39 \%$ to $43 \%$ of total fatty acids (Table 3). Omega-3 Polyunsaturated Fatty Acids (n-3 PUFAs) contributed to 36.6$40.0 \%$ of total fatty acids and $91-94 \%$ of PUFAs.

Table 2. Fatty Acid composition in fattened (stocking and harvested stages) and wild caught Scylla serrata from both Negombo and Kalpitiya lagoons

\begin{tabular}{|c|c|c|c|}
\hline Fatty Acid & $\begin{array}{l}\text { Wild caught } \\
\text { (IM I stage) }\end{array}$ & $\begin{array}{c}\text { Wild caught } \\
\text { (fattened } \\
\text { stage) }\end{array}$ & $\begin{array}{c}\text { Cage fattened } \\
\text { (fattened } \\
\text { stage) }\end{array}$ \\
\hline $\begin{array}{l}\text { C 14:0 } \\
\text { Mvristic }\end{array}$ & $1.06^{\mathrm{a}} \pm 0.3$ & $1.13^{\mathrm{a}} \pm 0.2$ & $1.31^{\mathrm{a}} \pm 0.5$ \\
\hline $\begin{array}{l}\text { C 15:0 } \\
\text { Pentadecanoic }\end{array}$ & $0.89^{\mathrm{a}} \pm 0.6$ & $0.86^{\mathrm{a}} \pm 0.2$ & $0.56^{\mathrm{b}} \pm 0.5$ \\
\hline $\begin{array}{l}\text { C 16:0 } \\
\text { Palmitic }\end{array}$ & $15.86^{\mathrm{a}} \pm 2.4$ & $16.89^{\mathrm{a}} \pm 2.8$ & $16.70^{\mathrm{a}} \pm 3.1$ \\
\hline $\begin{array}{l}\text { C 18:0 } \\
\text { Stearic }\end{array}$ & $6.17^{\mathrm{a}} \pm 8.7$ & $5.72^{\mathrm{a}} \pm 8.6$ & $8.14^{\mathrm{a}} \pm 8.8$ \\
\hline $\begin{array}{l}\text { C } 16: 1 \\
\text { Palmitoleic }\end{array}$ & $4.78^{\mathrm{a}} \pm 0.9$ & $4.28^{\mathrm{a}} \pm 1.4$ & $4.27^{\mathrm{a}} \pm 1.2$ \\
\hline $\begin{array}{l}\text { C 18:1 (n-9) } \\
\text { Oleic }\end{array}$ & $16.47^{\mathrm{a}} \pm 2.3$ & $15.92^{\mathrm{a}} \pm 2.2$ & $20.62^{\mathrm{b}} \pm 3.2$ \\
\hline $\begin{array}{l}\text { C 18:1 (n-7) } \\
\text { Vaccenic }\end{array}$ & $6.10^{\mathrm{a}} \pm 4.7$ & $3.83^{\mathrm{a}} \pm 1.4$ & $4.25^{\mathrm{a}} \pm 1.6$ \\
\hline $\begin{array}{l}\text { C 20:1 } \\
\text { Gondoic }\end{array}$ & $0.99^{\mathrm{a}} \pm 0.2$ & $0.88^{\mathrm{a}} \pm 0.6$ & $0.33^{\mathrm{b}} \pm 0.1$ \\
\hline $\begin{array}{l}\text { C 24:0 } \\
\text { Lignoceric }\end{array}$ & $1.37^{\mathrm{ab}} \pm 0.4$ & $1.57^{\mathrm{b}} \pm 0.5$ & $1.06^{\mathrm{a}} \pm 0.3$ \\
\hline $\begin{array}{l}\text { C 18:2 (n-6) } \\
\text { Linoleic }\end{array}$ & $1.52^{\mathrm{a}} \pm 0.5$ & $1.76^{\mathrm{a}} \pm 0.4$ & $1.61^{\mathrm{a}} \pm 0.3$ \\
\hline $\begin{array}{l}\text { C 20:4 (n-3) } \\
\text { Eicosatetraenoic }\end{array}$ & $11.64^{\mathrm{a}} \pm 3.9$ & $12.16^{\mathrm{a}} \pm 2.9$ & $11.05^{\mathrm{a}} \pm 3.1$ \\
\hline $\begin{array}{l}\text { C } 20: 5(n-3) \\
\text { Eicosapentaenoic }\end{array}$ & $15.48^{\mathrm{a}} \pm 2.3$ & $14.57^{\mathrm{ab}} \pm 1.9$ & $13.88^{\mathrm{b}} \pm 2.2$ \\
\hline $\begin{array}{l}\text { C 22:4 (n-6) } \\
\text { Docasatetraenoic }\end{array}$ & $1.44^{\mathrm{a}} \pm 0.6$ & $1.29^{\mathrm{a}} \pm 0.4$ & $1.02^{\mathrm{b}} \pm 0.4$ \\
\hline $\begin{array}{l}\text { C 22:5 (n-3) } \\
\text { Docasapentaenoic }\end{array}$ & $1.40^{\mathrm{ab}} \pm 0.5$ & $1.66^{\mathrm{a}} \pm 0.5$ & $1.33^{\mathrm{b}} \pm 0.4$ \\
\hline $\begin{array}{l}\text { C 22:6 (n-3) } \\
\text { Docasahexaenoic }\end{array}$ & $11.76^{\mathrm{a}} \pm 1.2$ & $11.14^{\mathrm{ab}} \pm 2.4$ & $10.45^{\mathrm{b}} \pm 2.6$ \\
\hline
\end{tabular}


Table 3. Summarized information on major groups of fatty acids in fattened (stocking and harvested stages) and wild caught Scylla serrata from both Negombo and Kalpitiya lagoons

\begin{tabular}{lccc}
\hline Fatty Acid & $\begin{array}{c}\text { Wild caught } \\
\text { (IM I stage) }\end{array}$ & $\begin{array}{c}\text { Wild caught } \\
\text { (fattened } \\
\text { stage) }\end{array}$ & $\begin{array}{c}\text { Cage fattened } \\
\text { (fattened } \\
\text { stage) }\end{array}$ \\
\hline Saturated & $23.25^{\mathrm{a}} \pm 8.4$ & $23.73^{\mathrm{a}} \pm 8.7$ & $26.4^{\mathrm{a}} \pm 8.4$ \\
MUFA & $25.8^{\mathrm{ab}} \pm 4.8$ & $23.92^{\mathrm{a}} \pm 4.4$ & $28.57^{\mathrm{b}} \pm 3.2$ \\
PUFA & $42.85^{\mathrm{a}} \pm 5.9$ & $42.23^{\mathrm{ab}} \pm 4.1$ & $38.97^{\mathrm{b}} \pm 5.8$ \\
& $40.03^{\mathrm{a}} \pm 5.7$ & $39.28^{\mathrm{a}} \pm 3.9$ & $36.56^{\mathrm{a}} \pm 5.4$ \\
Omega-3 & $91.9^{\mathrm{a}} \pm 3.8$ & $89.89^{\mathrm{a}} \pm 6.5$ & $93.95^{\mathrm{a}} \pm 2.4$ \\
$\begin{array}{l}\text { Omega-3 as a \% of } \\
\text { total PUFA }\end{array}$ & & \\
\hline $\begin{array}{l}\text { Data are presented as mean } \pm \text { SD of percentages. Mean values in the same } \\
\text { row followed by different letters are significantly different from each other }(\mathrm{p} \\
<0.05) .\end{array}$
\end{tabular}

\section{Comparison of fatty acid profiles of crabs from different sources (pooled data of two water bodies)}

Canonical discriminant analysis revealed that function 1 discriminate mostly between the fatty acid profiles of cage fattened crabs and the same of other two categories combined (Figure 1). The fatty acid profiles of cage fattened group showed $100 \%$ discrimination from the other two categories. Wild caught crabs (IM 1) showed 90.9\% discrimination from wild caught (fattened), but $27 \%$ of wild caught (fattened) also overlap with wild caught (IM I). Pentadecanoic acid (C15:0), Oleic acid (C18:1 n-9), Gondoic acid (C20:1) and Stearic acid (C18:0) mostly influence this discrimination of the categories.

As evident from ANOVA, percentage contents of Pentadecanoic acid (C 15:0), Oleic acid (C 18:1 n-9), Gondoic acid (C 20:1) and Docasatetraenoic acid (C 22:4 (n-6)) of the cage fattened (fattened stage) category was significantly different $(p<0.05)$ from other two categories. Furthermore, percentage contents of Lignoceric acid (C 24:0) and Docasapentaenoic acid (C 22:5 n-3)) of the cage fattened (fattened stage) category was significantly different $(\mathrm{p}<0.05)$ from the wild caught (fattened stage) category and significant differences $(p<0.05)$ were evident between the same category and wild caught (IM stage) category for Eicosapentaenoic acid (C 20:5 n-3) and Docasahexaenoic acid (C 22:6 n-3).(Table 2). In the case of major groups of fatty acids, ANOVA revealed that mean $\%$ of MUFA 
was significantly different $(\mathrm{p}<0.05)$ among wild caught (fattened stage) and cage fattened (fattened stage) categories. In addition, mean $\%$ of PUFA was significantly different $(\mathrm{p}<0.05)$ between wild caught (IM stage) and cage fattened (fattened stage) categories (Table 3 ).

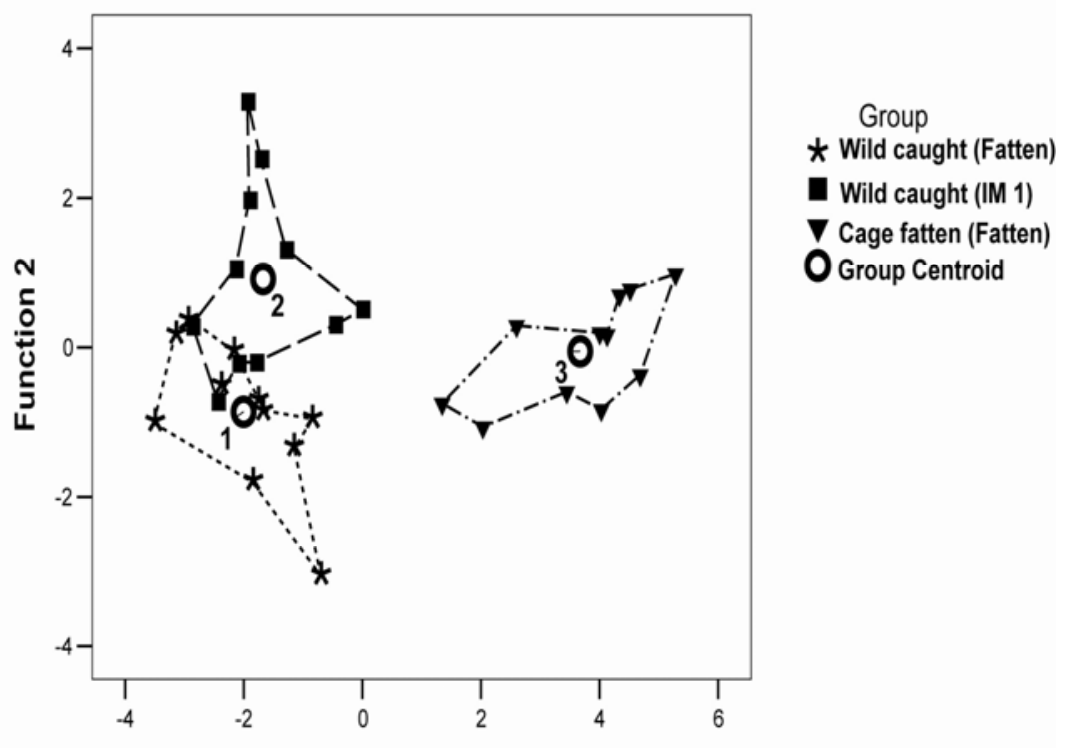

Function 1

Figure 1. Combined group plot of Canonical discriminant analysis based on fatty acid profiles of three groups of Scylla serrata from both Kalpitiya and Negombo lagoons

\section{Comparison of fatty acid profiles of crabs collected from two water bodies (pooled data of three categories)}

There were no separations of fatty acid profiles among crabs from two water bodies when discriminant analyses were performed for each of three categories separately. However, when the same analysis is performed for the pooled data from three categories, the mud crabs from the Negombo lagoon showed $100 \%$ discrimination from the crabs from Kalpitiya lagoon based on the fatty acid profile (Table 4).

Docasapentaenoic acid (C22:5 n-3), Myristic acid (C14:0) and Gondoic acid (C20:1) were the main causes of this discrimination of two categories. Myristic acid (C14:0), Gondoic acid (C20:1) and Docasapentaenoic acid $(\mathrm{C} 22: 5 \mathrm{n}-3)$ were significantly different $(\mathrm{P}<0.05)$ between the crabs from two water bodies according to the pooled $\mathrm{t}$ - test (Table 5). 
Table 4. Classification results of discrimination analysis for different locations based on the fatty acid profiles of Scylla serrata (pooled data of three categories)

\begin{tabular}{llrrr}
\hline & & \multicolumn{2}{c}{$\begin{array}{c}\text { Predicted Group } \\
\text { Membership }\end{array}$} & Total \\
\cline { 3 - 4 } & $\begin{array}{l}\text { Original Group } \\
\text { Membership }\end{array}$ & Negombo & Kalptiya & \\
\hline Count & Negombo & 12 & 0 & 12 \\
& Kalptiya & 0 & 12 & 12 \\
\hline$\%$ & Negombo & 100.0 & 0 & 100.0 \\
& Kalptiya & 0 & 100.0 & 100.0 \\
\hline
\end{tabular}

Table 5. Fatty Acid composition of Scylla serrata from Negombo and Kalpitiya lagoons

\begin{tabular}{|c|c|c|}
\hline \multirow{2}{*}{ Fatty Acid } & \multicolumn{2}{|c|}{ Water Body } \\
\hline & Negombo lagoon & Kalpitiya lagoon \\
\hline C 14:0 & $1.05^{\mathrm{a}} \pm 0.27$ & $1.31^{\mathrm{b}} \pm 0.42$ \\
\hline C 15:0 & $0.77^{\mathrm{a}} \pm 0.43$ & $0.82^{\mathrm{a}} \pm 0.47$ \\
\hline C 16:0 & $16.2^{\mathrm{a}} \pm 2.85$ & $16.8^{\mathrm{a}} \pm 2.77$ \\
\hline C 18:0 & $5.73^{\mathrm{a}} \pm 7.72$ & $7.79^{\mathrm{a}} \pm 9.17$ \\
\hline C $16: 1$ & $4.18^{\mathrm{a}} \pm 1.31$ & $4.54^{\mathrm{a}} \pm 1.15$ \\
\hline C 18:1 (n-9) & $18.2^{\mathrm{a}} \pm 3.79$ & $17.9^{\mathrm{a}} \pm 3.13$ \\
\hline C $18: 1(n-7)$ & $4.88^{\mathrm{a}} \pm 3.69$ & $4.32^{\mathrm{a}} \pm 1.74$ \\
\hline C 20:1 & $0.9^{\mathrm{a}} \pm 0.46$ & $0.37^{b} \pm 0.16$ \\
\hline C 24:1:0 & $1.32^{\mathrm{a}} \pm 0.34$ & $1.32^{\mathrm{a}} \pm 0.48$ \\
\hline C 18:2(n-6) & $1.55^{\mathrm{a}} \pm 0.39$ & $1.72^{\mathrm{a}} \pm 0.42$ \\
\hline C 20:4 (n-3) & $11.5^{\mathrm{a}} \pm 3.37$ & $11.6^{\mathrm{a}} \pm 3.25$ \\
\hline C $20: 5(n-3)$ & $14.8^{\mathrm{a}} \pm 1.84$ & $14.3^{\mathrm{a}} \pm 2.43$ \\
\hline C 22:4 (n-6) & $1.14^{\mathrm{a}} \pm 0.48$ & $1.3^{\mathrm{a}} \pm 0.46$ \\
\hline C $22: 5(n-3)$ & $1.17^{\mathrm{a}} \pm 0.34$ & $1.64^{\mathrm{b}} \pm 0.41$ \\
\hline
\end{tabular}

Data are presented as mean \pm SD of percentages. Mean values in the same row followed by different letters are significantly different from each other ( $p$ $<0.05)$. 


\section{Discussion}

The present study indicates that $S$. serrata contain very low amount of lipid $(0.53 \%-0$. 65\%). Typically in crustaceans (lobsters, crabs, and shrimps) the edible parts are low in fat (0.5-1.5\%) (Ackman 2000). The total lipid content of $S$. serrata was much lower than that of black tiger shrimp (Penaeus monodon) (3.6-3.7\%) (Croos et al. 2005). However biochemical composition of S. serrata changes seasonally (Zafar et al. 2004). Therefore if the present study was continued for a longer period, there might be some deviations from the present results observed for lipid content.

Saturated fatty acids contributes to major proportion of fatty acid profiles of many species of fish (Edirisinghe et al. 1998) and wild caught and cultured Penaeus monodon (Croos et al. 2005). In contrast only a minor proportion of fatty acid profile was represented by SFAs in S. serrata. Also the percentages of MUFAs and PUFAs recorded from the $S$. serrata were considerably high compared to those of some other seafood (Edirisinghe et al. 1998) and wild caught Penaeus monodon (Croos et al. 2005).

The percentage of n-3 PUFA of S. serrata recorded from the present study was considerably higher than that of Penaeus monodon (Croos et al. 2005). The most biologically active PUFAs viz, Eiciosapentaenoic acid (EPA), (C 20:5 n-3) and Docosahexaenoic acid (DHA), (C 22:6 n-3) are reported to contribute to highest proportion of total n-3 PUFAs in most species (Edirisinghe et al. 1998). The same was evident from the present study. Also EPA and DHA contents recorded in the present study showed that content of EPA (C 20:5 n-3) $\geq$ content of DHA (C 22:6 n-3) which is a distinguish feature of crustaceans and mollusks(Ackman 2000).

The present investigation shows that the fatty acid profile of the cage fattened crabs (fattened stage) was distinct from other two categories. The reason behind might be the differences in naturally available food sources and feed used in the fattening practices (fish offal, skates, clams, etc.). It was evident from the previous studies that the crustacean fatty acid profiles are influenced by the changes in the nutritional composition of the diet and by changes in the dietary sources (O'leary and Mathews 1990; D'Abramo and Sheen 1993; Deering et al. 1997; Lim et al. 1997; Sheen and Wu 1999). The fatty acid profile discrimination of the crabs from two water bodies might be due to variations in available food sources, physiochemical parameters such as salinity, temperature, etc. O'leary and Mathews (1990) suggested that the prawn fatty acid composition might reflect the differences in diet and environment. The differences in fatty acid composition among wild caught (fattened stage) and cage fattened (fattened stage) might be a reason for flavour difference between the two types. Furthermore these differences could be used to distinguish wild caught mud crabs from fattened mud crabs. The present study suggested that further investigations have to be carried out to determine effect of diet on fatty acid composition of S. serrata. 


\section{Acknowledgements}

The authors wish to express their gratitude to Director General of National Aquatic Resource Research and Development Agency for providing necessary facilities for the study; the staff of Post Harvest Technology Division, NARA for their assistance in the study; Mr. M.D.S.T.D. Croos, Ms. P.V.S.L. Gunawardene, Ms. D.S. Silva and Ms K.A.T. Dananjanie of Department of Aquaculture and Fisheries, Wayamba University of Sri Lanka who supported for the study; Mr. Asitha, Negombo and Mr. Human, Kalpitiya for providing the crab samples.

\section{References}

Ackman, R.G. 2000.

Fatty acid in fish and shellfish In: Fatty Acids in Food and Their Health Implications. (C.K. Chow, ed), pp. 153-174, $2^{\text {nd }}$ ed., Marcel Dekker Inc, USA.

Anonymous 2002.

Lagoon Crab Culture (Kalapu Kakulu Wagawa), pp. 5-9, National Aquaculture Development Authority of Sri Lanka, Sri Lanka.

Berner, L \& J. Berner. 1994.

FF-FAME-GC method, Lyngby, Denmark. 20p.

Bliss, E.D. 1990.

Shrimps, Lobsters and Crabs, Their Fascinating Life History, 242 p. Columbia University Press, USA.

Croos, M.D.S.T.D., J.M.P.K. Jayasinghe, E.M.R.K.B. Edirisinghe \& D.N. Silva 2005.

Lipid composition and fatty acid profiles of wild caught and cultured black tiger shrimp, Penaeus monodon, in Sri Lanka. Sri Lanka Journal of Aquatic Sciences 10: 35-43.

Deerling, M.J., D.R. Fielder \& D.R. Hewitt 1997.

Growth and fatty acid composition of juvenile leader prawns, Penaeus monodon, fed with different lipids. Aquaculture 151:131141.

D'Abramo, L.R. \& S.S. Sheen 1993.

Polyunsaturated fatty acid nutrition in juvenile fresh water prawn Macrobachium rosenbergii. Aquaculture 115:63-86.

Edirisinghe, E.M.R.K.B., W.M.K. Perera, S. Jayasoriya \& A. Bamunuarachchi 1998.

Health related fatty acids in some pelagic fishes in Sri Lanka. Sri

Lanka Journal of Aquatic Sciences 3: 97-107.

Hanson, S.W.F. \& J. Olly 1965.

Application of Bligh and Dyer method of lipid extraction to tissue homogenates. Biochemical Journal 89:101-102.

Hwang, H.D. 2000. 
Fatty acids and eicosanoids. In: Fatty Acids in Food and Their Health Implications (C.K.Chow, ed), pp 585-593, $2^{\text {nd }}$ ed. Marcel Dekker Inc, USA.

Jayamanne, S.C. 1992.

The mud crab fishery of Sri Lanka. In: Report of the Seminar on Mud Crab Culture and Trade. (C.A. Angell eds), pp 41-48, Bay of Bengal Programme, Madras.

Lim, C., H. Ako, C.L. Brown \& K. Hahu 1997.

Growth responses and fatty acid composition of juvenile Penaeus vannamei fed different diet sources of diet lipids. Aquaculture 151; $143-153$

Oleary, C.D. \& A.D. Mathews 1990.

Lipid class distribution and fatty acid composition of wild and farmed prawn, Penaeus monodon. Aquaculture 89: 65-81

Sheen, S.S. \& S.W. Wu 1999.

The effect of dietary lipid levels on growth response of juvenile mud crab Scylla serrata. Aquaculture 175:143-153.

Zafar, M., M.Z.H. Siddiqui \& M.A. Hoque 2004.

Biochemical composition in Scylla serrata (Froskal) of Chakaria Sundrban area, Bangladesh. Pakistan Journal of Biological Sciences 7 (12):2182-2186 
